\title{
INOVASI PEMBELAJARAN \\ MELALUI PENELITIAN DAN PENGEMBANGAN BAHAN AJAR
}

\author{
Oleh : Dr. Erlina, M.Pd
}

\begin{abstract}
Abstrack
Learning innovation is a necessity that must be done in order to increase the quality of education. Learning innovation is needed in many aspects and factors of education, such as good facilities, curriculum, learning process, evaluation of education and improvement of teachers and the leraning participant quality. This article presents the idea of educational innovation in the development of teaching materials. There are three ways that can be used in developing teaching materials, namely: (1) writing itself (starting from scratch), (2) repackaging information, (3) structuring information (compilation). Teaching materials must meet the criteria: the accuracy of the content, the precision of coverage, the legibility of teaching materials, the use of language, packaging, illustrations, and completeness of the component. To produce teaching materials, need to be done through the stages of research and development, including: discover the potential and problems, data collection, product design, design validation, revision, product testing, product revision, utility testing, product revision, and mass production.
\end{abstract}

Keywords: Learning innovation, Teaching materials, Research and development. 


\section{A. Pendahuluan.}

Pada awalnya R \& D merupakan hasil pengamatan berbagai gejala yang muncul di masyarakat pendidikan yang menuntut penciptaan produk pendidikan untuk jangka panjang. Jenis penelitian $\mathrm{R} \& \mathrm{D}$ (Research and Development) atau penelitian dan pengembangan menurut Semiawan merupakan perbatasan dari pendekatan kualitatif dan kuantitatif yang bertujuan menjembatani kesenjangan antara penelitian dan praktik pendidikan ${ }^{1}$.

Borg Dan Gall dalam Sugiojono menjelaskan bahwa metode penelitian dan pengembangan telah banyak digunakan dalam bidang ilmu-ilmu alam dan teknik, tetapi masih sangat sedikit dalam bidang ilmu-ilmu sosial dan pendidikan, yaitu kurang dari $1 \%$ dari biaya pendidikan secara keseluruhan. ${ }^{2}$

Metode penelitian ini bertujuan untuk menghasilkan produk tertentu, dan menguji keefektifan produk tersebut. Pendekatan yang digunakan dalam R \& D adalah kombinasi antara pendekatan kuantitatif dan kualitatif. Penciptaan ataupun rekayasa produk tertentu yang dapat berfungsi dan berguna di masyarakat perlu dilakukan penelitian pendahuluan yang disebut analisis kebutuhan lalu dilanjutkan uji keefektifan produk. Karena itu, penelitian dan pengembangan bersifat longitudinal.

\section{B. Konsep Inovasi Pembelajaran}

Inovasi berarti new ideas, kata inovasi (innovation) juga berarti pembaharuan, juga berasal dari kata kerja innovate yang berarti make change atau introduce new thing (ideas or techniques) in order to make progress. Inovasi adalah suatu gagasan (ide), praktik, atau obyek yang dapat dipahami sebagai sesuatu yang baru, atau mengadopsi dari sesuatu yang sebenarnya sudah ada dengan memodifikasinya.

Inovasi dapat dipahami dan diterima bergantung pada karakteristik yang dimilikinya:

${ }^{1}$ Semiawan, Conny R. Catatan Kecil Tentang Penelitian dan Pengembangan Ilmu Pengetahuan. Jakarta: Kencana. 2007:181.

${ }^{2}$ Sugioyono. Metode Penelitiian Dan $R \&$ D, Alpabeta, Bandung. 2008:298. 
1. Nilai keuntungan, ide tersebut harus lebih baik daripada yang digantikannya, yang dapat diukur oleh istilah istilah ekonomi, prestise sosial, keramah-tamahan, dapat memberi kepuasan bagi pengguna dan masyarakat,

2. Kecocokan, yaitu kesesuaian dengan nilai yang mapan, pengalaman masa lalu dan dapat memenuhi kebutuhan,

3. Tingkat kerumitan, inovasi yang mudah dipahami dan digunakan lebih mudah diterima masyarakat, sebaliknya yang kesulitannya tinggi tidak mudah diterima,

4. Dapat dicoba, inovasi yang dapat dicoba lebih mudah diterima, dapat diobservasi, yaitu sebuah inovasi yang dapat terlihat untuk diteliti. ${ }^{3}$

Sementara pembelajaran merupakan terjemahan dari learning yang artinya belajar, atau pembelajaran. Jadi, inovasi pembelajaran adalah pembaharuan pembelajaran yang dikemas atas dorongan gagasan barunya yang merupakan produk dari learning how to learn untuk melakukan langkah-langkah belajar, sehingga memperoleh kemajuan hasil belajar. Istilah learning how to learn mengandung ide, gagasan tentang teknik, memfasilitasi peserta didik untuk memperoleh kemajuan dalam proses dan hasil belajar.

Maka hakikat inovasi pembelajaran adalah ide, gagasan baru tentang berbagai faktor yang dapat mendorong terjadinya pembelajaran yang lebih baik dan tepat guna. Secara harfiah inovasi pembelajaran dapat disebut pembaharuan pembelajaran. Inovasi pembelajaran bagian dari inovasi pendidikan, yaitu usahausaha dengan melakukan perubahan untuk mencapai suatu yang lebih baik dalam bidang pendidikan ${ }^{4}$.

Gagasan pembaharuan muncul karena adanya masalah atau krisis baik pada paradigma ataupun praktik pendidikan dan pembelajaran, atau bahkan tekanan sosial yang tidak lagi dapat menerima kondisi yang ada. Berbagai masalah ini mendorong kita pada perubahan paradigma dan corak praktik

\footnotetext{
${ }^{3}$ Rogers, Everett M, Diffusion of Inovations. USA, 1995

${ }^{4}$ Udin Saefudin Sa'ud, Inovasi Pendidikan, Bandung, Alfabeta, 2008: h. 8
} 
pendidikan dan pembelajaran baru yang diyakini mampu memecahkan masalah tersebut.

Inovasi pembelajaran biasanya berawal dari hasil refleksi terhadap eksistensi paradigma lama menuju paradigma baru yang dianggap mampu memecahkan masalah atau mampu memperbaiki praktik pendidikan. Terkait dengan masalah perkuliahan di perguruan tinggi, diantaranya kecenderungan belajar berbasis fakta, isi pelajaran dan teori, bukan berbasis kebutuhan dan penyelesaian masalah, penggunaan bahan ajar, media statis, komunikasi terbatas satu arah dan penilaian lebih bersifat normatif.

Perubahan paradigma pendidikan seyogyanya mengakomodasi berbagai kepentingan hidup masyarakat karena pendidikan adalah salah satu alat untuk memajukan kehidupan masyarakat, jika tidak proses pendidikan dan pembelajaran itu sia-sia dan tidak bermanfaat. Paradigma baru pembelajaran sebagai produk inovasi, dari sisi proses mestinya lebih menyediakan proses belajar yang mengembalikan hakikat siswa ke fitrahnya sebagai manusia yang memiliki sejumlah potensi dasar yang harus dikembangkan sehingga menjadi manuasia yang baik dan berguna bagi masyarakatnya. Inovasi harus berorientasi pada pencapaian tujuan belajar oleh siswa secara aktif dan memberi kemudahan belajar untuk siswa, siapapun fasilitator yang menemani siswa belajar.

Keberhasilan suatu inovasi pendidikaan dan pembelajaran bergantung pada sejauh mana pengetahuan dan kecakapan guru dalam melaksanakan tugas di sekolah- termasuk pemahaman terhadap kurikulum. Mutlak bagi pendidik untuk memahami tentang inovasi kurikulum dalam melakukan pembelajaran. Tanpa pemahaman tentang inovasi kurikulum, sulit bagi pendidik untuk mampu memajukan pendidikan di suatu masyarakat.

\section{Ranah Inovasi Pembelajaran}

Upaya-upaya inovasi dalam bidang pendidikan dan pembelajaran merupakan suatu keniscayaan yang harus terjadi jika suatu lembaga pendidikan, masyarakat ataupun suatu bangsa ingin lebih maju dan tidak tertinggal.

Beberapa ranah atau aspek pembelajaran yang harus mendapat sentuhan pembaharuan atau inovasi, yaitu: 
1) Peserta didik, dalam hal ini inovasi dapat berupa pengelompokan peserta didik dalam proses pembelajaran berdasarkan karakteristiknya.

2) Tujuan pendidikan, inovasi tujuan pendidikan terkait kapasitas pribadi yang harus dimiliki peserta didik, terkait perannya sebagai warga sosial, ekonomis, tingkat kecakapan dan jenis pengajaran, cara dan sarana berpengaaruh dan menjadi dasar dalam merumuskan tujuan pendidikan

3) Isi pelajaran, inovasi dapat dilakukan menurut jenisnya, dampaknya, kapasitas anak didik, struktur ilmu pengetahuan, manfaat, kemampuan mental, dan derajat spesialisasi.

4) media pembelajaran,

5) Fasilitas pendidikan, inovasi dapat berupa penyediaan perabot/perlengkapan yang mendukung pelaksanaan pendidikan

6) Metode dan tekhnik komunikasi, inovasi dapat berupa interaksi langsung dan tak langsung, metoda dan teknik pembelajaran.

7) Hasil pendidikan. ${ }^{5}$

Pada tulisan ini penulis berupaya untuk menyampaikan gagasan inovasi pembelajaran berupa pengembangan bahan ajar.

\section{Bahan Ajar}

Bahan ajar itu adalah isi pembelajaran berupa materi, konsep, pengetahuan, keterampilan, pengalaman dan sikap atau nilai-nilai yang digunakan sebagai bahan interaksi antara pendidik dan peserta didik. Bahan ajar dirancang sedemikian rupa untuk mencapai tujuan tertentu dan disusun dengan sistematika tertentu dan penyampaiannya pun disesuaikan dengan karakteristik mata pelajaran dan karakteristik peserta didik yang menggunakannya. Belawati menjelaskan: Bahan ajar adalah segala hal yang dapat digunakan dalam kegiatan belajar, baik berupa bahan ajar tertulis maupun tidaak tertulis. ${ }^{6}$

Suatu bahan ajar harus sesuai dengan tujuan yang akan dicapai peserta didik dalam proses belajar. Tujuan belajar harus memuat aspek: pengetahuan,

${ }^{5}$ Op.cit. h. 9 dan (http://www.academia.edu/7340648/ruang_lingkup_inovasi_pendidikan)

${ }^{6}$ Arman Husni. Pengembangan Bahan Ajar bahasa arab Untuk Pemula, versi online Jurnal Ittijah. Vol 02. No .01 (Jnauari-Juni) 2010. h. 3. diunduh 20 Februari 2016. Tian Belawati dkk. Pengembangan Bahan Ajar, Jakarta : Pusat Penerbitan Universitas Terbuka. 2003;1.3. 
sikap dan keterampilan. Demikian juga bahan ajar harus meliputi: pengetahuan (fakta, konsep, prosedur, prinsip) keterampilan dan sikap atau nilai. ${ }^{7}$ Bahan ajar dapat berfungsi sebagai pemberi arah terlaksananya proses pembelajaran. Oleh karena itu, bahan ajar harus dapat menggambarkan aspek-aspek penting rencana kegiatan pembelajaran. Menurut Abdul Majid bahan ajar itu harus memuat informasi tentang: petunjuk belajar (bagi pendidik dan peserta didik), kompetensi atau tujuan yang akan dicapai,informasi pendukung,latihan, latihan,petunjuk kerja (Lembar Kerja) ,dan evalauasi. ${ }^{8}$

Bahan ajar bermanfaat bagi pendidik dan peserta didik. Manfaat bahan ajar bagi pendidik adalah: 1. Menghemat waktu pendidik dalam mengajar; 2 . Mengubah peran pendidik dari seorang pengajar menjadi seorang fasilitator; meningkatkan proses pembelajaran menjadi lebih efektif fan interaktif. Sedangkan manfaat bahan ajar bagi peserta didik: 1. mendidik Peserta didik menjadi mandiri; 2. Peserta didik dapat mengulangi, kapan saja dan dimana saja ia kehendaki; 3 . Peserta didik dapat belajar sesuai kecepatannya sendiri; peserta didik dapat belajar menurut urutan yang dipilihnya sendiri; membantu mengembangkan potensi peserta didik untuk menjadi pelajar yang mahir dan berbakat serta mandiri.

\section{Teknik Penyusunan Buku Ajar}

Penyusunan buku ajar dapat dilakukan dengan berbagai cara, dari yang termurah sampai yang termahal, dari yang paling sederhana sampai yang tercanggih. Secara umum, ada tigacara yang dapat digunakan pendidik dalam menyusun bahan ajar, yaitu: (1) menulis sendiri (starting from scratch), (2) pengemasan kembali informasi (information repackaging), (3) penataan informasi (compilation).

\section{(1) Menulis Sendiri}

Pendidik dapat menulis sendiri buku ajar yang akan digunakan dalam perkuliahan. Asumsi yang mendasari cara ini, bahwa pendidik merupakan pakar yang dipercaya dalam bidang ilmu yang ditekuninya, mempunyai kemampuan menulis, dan mengerti kebutuhan peserta didik. Pendidik

\footnotetext{
${ }^{7}$ Abdul Majid, Perencanaan Pembelajaran Mengemabangkan Standar Kompetensi Guru, Bandung, Rosda karya. 2007. h. 173

${ }^{8}$ Ibid., h. 174
} 
sebagai pakar bidang i!mu (dapat secara individual maupun tim) menulis bahan ajar yang akan digunakan dalam proses perkuliahan.

Penulisan bersama dengan beberapa pakar di bidang ilmu yang sama merupakan cara yang baik karena cepatnya perkembangan dibidang ilmu dewasa ini. Penulisan buku ajar oleh beberapa pakar dapat menambah kredibilitas buku ajar tersebut bagi pemakai (Peserta didik dan Pendidik di Perpendidikan Tinggi Lainnya).

Disamping penguasaan bidang ilmu, penulisan bahan ajar harus berpedoman pada prinsip-prinsip pembelajaran dan karakteristik ilmu pengatahuan dan berlandaskan pada kebutuhan peserta didik, meliputi kebutuhan akan: pengetahuan, keterampilan, bimbingan, latihan, dan kebutuhan umpan balik.

Pendidik dapat mengetahui kebutuhan peserta didik berdasarkan:

1. Analisis perkuliahan yang telah dibuat untuk mata kuliah yang dibinanya,

2. Berdasarkan silabus (hasil rekonstruksi mata kuliah), dan

3. Berdasarkan kontrak perkuliahan yang telah disusun.

Jadi materi yang disajikan dalam buku ajar adalah pokok bahasan dan sub pokok bahasan yang tercantum didalam silabi yang meliputi seluruh perkuliahan sesuai ruang lingkup kuliah yang disusun dalam kontrak perkuliahan. Analisis kebutuhan belajar peserta didik dapat dilakukan oleh pendidik sendiri atau dengan bantuan perancang perkuliahan.

Penulisan buku ajar yang dilakukan oleh pendidik sendiri merupakan cara yang paling ekonomis, walaupun beban pendidik menjadi cukup berat. Hasil dari penulisan buku ajar yang dilakukan oleh pendidik sendiri bukan cuma sekedar seperangkat buku ajar yang dapat dipergunakan oleh pendidik dan peserta didik dalam proses perkuliahan. Namun dari proses penulisan buku ajar tersebut, pendidik juga memperoleh keterampilan baru, yaitu keterampilah menulis buku ajar.

\section{(2) Pengemasan Kembali Informasi (Information Repackaging)}

Dalam pengemasan kembali informasi, pendidik tidak menulis buku ajar dari awal (from nothing atau from scratch), tetapi pendidik memanfaatkan buku-buku teks dan informasi yang sudah ada di pasar untuk dikemas kembali sehingga berbentuk buku ajar yang memenuhi karakteristik 
buku ajar yang baik, dan dapat dipergunakan oleh pendidik dan peserta didik dalam proses perkuliahan.

Informasi yang sudah ada di berbagai bahan bacaan dikumpulkan berdasarkan kebutuhan (sesuai silabi, kontrak perkuliahan). Kemudian, disusun kembali atau ditulis ulang dengan gaya bahasa dan strategi yang sesuai untuk menjadi suatu buku ajar, juga diberi tambahan kompetensi yang akan dicapai, bimbingan belajar bagi peserta didik, latihan dan tes formatif, dan umpan balik bagi peserta didik agar mereka dapat mengukur sendiri kemampuan yang telah dicapai.

Pengemasan kembali informasi memerlukan keterampilan menulis ulang, menggubah dan melengkapi informasi-informasi tersebut untuk menjadi suatu buku ajar yang baik. Dalam proses ini pendidik perlu menentukan seberapa banyak perubahan yang perlu dilakukan terhadap bahan yang sudah ada, kemudian apakah perubahan tersebut dapat dilakukan dalam batas waktu yang ditentukan, dengan sumber daya yang tersedia, dan seijin atau sepengetahuan pengarang asli.

Pengemasan kembali informasi merupakan proses penyusunan buku ajar yang jauh lebih cepat jika dibandingkan dengan penulisan dari awal. Namun, proses ini dapat menjadi mahal, karena memerlukan proses memperoleh ijin dari pengarang asli. Kegiatan penyusunan buku ajar dengan cara pengemasan kembali informasi ini selain menghasilkan buku ajar yang digubah dari buku teks atau informasi yang ada di pasaran, juga memberikan pengetahuan dan keterampilan kepada pendidik untuk mengubah buku teks dan informasi yang ada menjadi suatu buku ajar yang berkualitas dan dapat digunakan oleh pendidik dan peserta didik dalam perkuliahan.

\section{(3) Penataan Informasi (Compilation)}

Selain menulis sendiri, pengembangan buku ajar juga dapat dilakukan dengan cara mengkompilasi seluruh bahan atau buku ajar yang diambil dari buku teks, jurnal ilmiah, artikel, dan lain-iain. Proses pengembangan buku ajar dengan melakukan penataan informasi (kompilasi) ini hampir mirip dengan proses pengemasan kembali informasi. Namun dalam proses penataan informasi tidak ada perubahan yang dilakukan 
terhadap bahan kuliah yang diambil dari buku teks, materi audio-visual, dan informasi lain yang sudah ada di pasar.

Materi-materi tersebut dikumpulkan, difotocopy dan digunakan secara langsung. buku teks, materi audio-visual dan informasi lain yang akan digunakan sebagai materi inti dari buku ajar dipilih, dan disusun berdasarkan kompetensi yang akan dicapai, silabi, dan urutan perkuliahan yang tercantum dalam kontrak perkuliahan, demikianlan proses pengembangan bahan ajar melalui kompilasi.

Penataan informasi untuk menyusun buku ajar dapat dilakukan sendiri oleh pendidik. Proses ini merupakan proses yang paling ekonomis dan tidak membutuhkan waktu yang banyak. Yang diperlukan adalah keterampilan pendidik dan waktu untuk mengumpulkan buku teks materi audio-visual dan informasi lain melalui penelusuran literatur di perpustakaan, seleksi materi di toko buku, dan seleksi informasi-informasi yang actual di koran, majalah ilmiah, dan Iain-Iain.

Materi yang dikumpulkan disesuaikan dengan acuan standar kompetensi gramatika (kaidah nahwu dan shorf) yang tercantum dalam silabus mata kuliah. Materi-materi tersebut disusun secara berurutan berdasarkan standar kompetensi yang ditetapkan. Dalam penyusunan bahan ajar perlu disediakan halaman penyekat antar judul materi yang berisi informasi tentang urutan pertemuan, kompetensi yang akan dicapai, deskripsi singkat, bahan bacaan yang dikompilasi, tugas, serta hal-hal lain yang perlu diketahui peserta didik sehubungan dengan sesi tersebut.

\section{Kriteria Bahan Ajar}

Pengembangan bahan ajar perlu dirancang berdasarkan suatu proses sistematik agar kesahihan dan keterpercayaan bahan ajar dapat dijamin. Pengembangan bahan ajar harus mempertimbangkan 7 (tujuh) faktor: Kecermatan isi, ketepatan cakupan, ketercernaan bahan ajar, penggunaan bahasa, perwajahan/pengemasan, ilustrasi, kelengkapan komponen. 
Rancangan bahan ajar yang baik harus harus memenuhi beberapa kriteria kelayakan, Kementerian Pendidikan Nasional telah menetapkan kriteria bahan ajar yang meliputi: kelayakan isi, penyajian, bahasa, kegrafikan. ${ }^{9}$

\section{(1) Kelayakan isi}

Ditinjau dari isi bahan ajar kualitas bahan ajar cetak mencakup beberapa komponen yaitu; (a) kesesuaian isi dengan SK mata kuliah atau mata pelajaran dan Kompetensi Dasar, (b) kesesuaian isi dengan taraf perkembangan peserta didik, (c) kesesuaian dengan kebutuhan, (d) kesesuaian substansi materi ajar, (e) memperluas wawasan, (f) sesuai dengan nilai moral dan nilai- nilai yang berlaku.

\section{(2) Kelayakan penyajian}

Bahan ajar yang baik harus memenuhi kriteria penyajian tertentu yang terdiri dari beberapa komponen yaitu; (a) kejelasan tujuan (indikator) yang ingin dicapai, (b) urutan sajian, (c) memotivasi, memiliki daya tarik, (d) menggambarkan interaksi (pemberian stimulus dan respon), (e) informasinya lengkap.

\section{(3) Kelayakan bahasa}

Dari sisi bahasa, suatu bahan ajar cetak harus memenuhi kriteria yang terdiri dari beberapa komponen yaitu; (a) keterbacaan, (b) kejelasan informasi, (c) menggunakan kaidah Bahasa yang baik dan benar, (d) menggunakan bahasa efektif dan efisien (jelas dan singkat).

\section{(4) Kelayakan Kegrafikan}

Kriteria kualitas bahan ajar cetak dalam aspek kegrafikan meliputi beberapa komponen yaitu; (a) penggunaan huruf, jenis dan ukuran, (b) tata letak tepat dan menarik, (c) ilustrasi, gambar, foto, (d) desain.

Berdasarkan uraian penjelasan tersebut bahan ajar yang akan harus berlandaskan empat aspek kelayakan tersebut. Selain itu, pengembangan bahan ajar bahasa khususnya bahan qira'ah perlu memenuhi criteria berikut: sesuai dan dapat digunakan melalui strategi membaca bottom up ataupun Top Down,

\footnotetext{
${ }^{9}$ (www.diknas.go.id, diunduh pada 02 November 2013)
} 
memberi peluang untuk meningkatkan kecepatan, kelancaran,dan ketepatan bacaan secara seimbang, mencakup berbagai jenis teks,gaya retorika, ragam bahasa dan topic, mendorong siswa untuk menilai kemampuan mereka sendiri, memperkenalkan kepada siswa terhadap berbagai jenis bimbingan arahan yang diwujudkan dalam teks dan tes.membantu siswa untuk mengenali dan membangun informasi budaya yang dibutuhkan untuk menginterpretasi teks,

\section{Tahapan pengembangan bahan ajar}

Dalam mengembangkan dan merancang bahan ajar perlu mngikuti langkahlangkah sebagai berikut:

1. Pengkajian Kurikulum: mengkaji profil Lulusan, mengkaji kesesuaian kompetensi dengan KD, Indikator, dan memilih Materi. .

2. Perumusan Judul-judul materi (mempertimbangkan rambu-jambu pemilihan judul) berdasarkan kompetensi, menyeleksi judul-judul.

3. Mengumpulkan buku-buku dan sumber bahan lainnya. ${ }^{10}$

Penerapan tahap di atas dalam pengembagan bahan ajar pembelajaran bahasa Arab khususnya materi Qira'ah dilakukan dengan: mengkaji kurikulum yang ada, melihat profil lulusan yang diharapkan, capaian pembelajaran yang diinginkan (Standar Kompetensi mata kuliah Nahwu, Shorf dan Maharah Qira'ah) meninjau kesesuaian materi dan kompetensi dasarnya serta indikator kompetensi dalam ke 3 mata kuliah tersebut, menelaah kesesuaian KBM dengan Indikator kompetensi dan acuan penilaian. Tahap selanjutnya pengembang perlu melakukan analisis kebutuhan terhadap tema-tema teks Qira'ah dengan melakukan jajak pendapat terhadap peserta didik dan pendidik mata kuliah terkait melalui angket dan wawancara sehingga diketahui tema-tema yang sesuai dengan kebutuhan.

Hasil analisis kebutuhan tentang tema-tema bacaan ini dilanjutkan dengan seleksi judul-judul, dengan demikian maka bahan ajar yang dihasilkan betul-betul sesuai kebutuhan, minat, dan bermanfaat bagi peserta didik. Setelah dihasilkan judul-judul yang diinginkan kegiatan berikutnya pengumpulan buku-buku bacaan, sumber bahan lain yang sesuai.

${ }^{10}$ Kementerian Pendidikan nasional, Prosedur Penyusunan Bahan Ajar Modul, (Jakarta. Diknas., Tahun 2011. (Www.Diknas.go.id, diunduh tanggal 02 November 2013). 
Pengembangan bahan ajar yang tepat dan baik, perlu perencanaan yang matang serta dilakukan dalam serangkaian kegiatan penelitian dan pengembangan produk berupa bahan ajar agar efektifitas dan kehandalan bahan ajar yang dihasilkan betul-betul teruji dan sesuai dengan kebutuhan.

\section{Penelitian \& Pengembangan (R\&D) dalam Pembelajaran Bahasa}

Richey dan Klein pada awalnya menggunakan istilah developmental research untuk metode $R \& D$. Akan tetapi melalui berbagai diskusi dengan para kolega dan mahasiswanya ternyata kata "developmental" menimbulkan kebingungan karena menunjuk pada banyak bidang studi, seperti human development, international development, organizational development, dan staff development, sehingga digunakanlah istilah 'Design and Development Research' (DDR). Design and Development Research' (DDR) yang didefinisikan sebagai berikut: "the systematic study of design, development and evaluation processes with the aim of establishing an empirical basis for the creation of instructional and non-instructional products and tools and new or enhanced models that govern their development" 11

$D D R$ adalah studi sistematis tentang suatu rancangan, pengembangan dan proses evaluasi dengan tujuan menetapkan suatu dasar empiris untuk menciptakan produk dan alat instruksional dan non-instruksional serta modelmodel yang baru dan maju. Seels dan Richey (1994) memandang rancangan sebagai fase perencanaan tentang spesifikasi produk dibuat, dan pengembangan sebagai fase produksi di mana spesifikasi rancangan diaktualisasikan. ${ }^{12}$

Riset desain memiliki beberapa karakter:

1. Bersifat intervensi: tujuan riset mendesain dan melakukan intervsnsi dalam dunia nyata.

2. Iteratif: riset merupakan rangkaian siklus desain, evaluasi dan revisi.

3. berorientasi proses: tidak sekedar penilaian hasil akhir, melainkan focus pada pemahaman masalah dan meningkatkan intervensi untuk perbaikan.

\footnotetext{
${ }^{11}$ Richey dan Klein, Design and development research-methods, strategies and issues. London: Lawrence Erlbaum Associates, Inc., Publishers, 2007:1

12 Ibid.
} 
4. Berorientasi pada kegunaan: desain dinilai baik secara praktis bagi pengguna dalam konteks nyata.

5. Berorientasi pada teori: Desain yang disusun berbasis pada teori, minimal secara parsial atau sebagian.

6. Melahirkan proposisi; uji lapangan desain memberi kontribusi pada pembentukan teori. ${ }^{13}$

Proses analisis kebutuhan dan tujuan belajar yang menyeluruh serta pengembangan sistem penyampaian untuk memenuhi kebutuhan; mencakup pengembangan materi, kegiatan pembelajaran; ujicoba dan revisi semua kegiatan pengajaran dan penilaian aktivitas pembelajar.

Menurut Richey dan Klein $^{14}$, penelitian desain pembelajaran dan pengembangan memiliki enam komponen utama yaitu

1) pembelajar dan bagaimana mereka belajar;

2) konteks di mana pembelajaran dan performa berlangsung;

3) sifat dari isi dan bagaimana urutannya;

4) strategi pengajaran dan kegiatan yang dilaksanakan;

5) media dan sistem penyajian;

6) para perancang sendiri dan proses yang mereka gunakan.

Ke enam komponen utama tersebut terlihat pada gambar berikut:

13 Jan van den Akker. at All. Educational Design Research. p. 5

${ }^{14}$ Richey dan Klein, op.cit. p. 3 


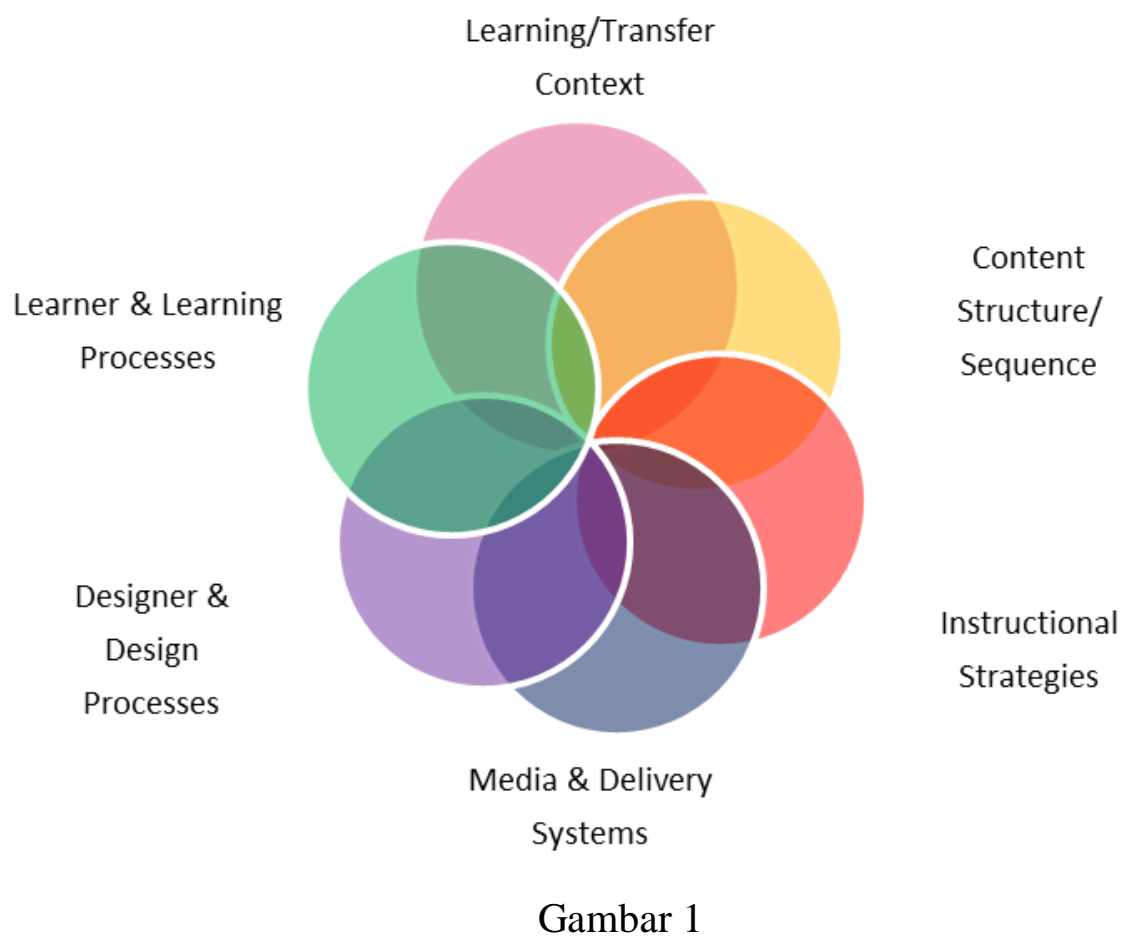

Desain Pengajaran dan Pengembangan Berbasis Pengetahuan)

Menurut Richey \& Klein ${ }^{15}$

Penelitian dan teori yang berpengaruh besar terhadap pengetahuan rancangan dan pengembangan adalah:

1. Psychological and learning theory and research (teori psikologi, teori belajar dan penelitian). Penelitian dan teori ini berkaitan dengan: (a) peserta didik dan proses belajar; (b) konteks pembelajaran dan transfer belajar; (c) strategi instruksional.

2. Instructional theory and teaching-learning theory. (Teori pengajaran dan Teori pembelajaran), teori-teori ini berkaitan dengan: (a) struktur isi materi ajar dan urutannya; (b) strategi pengajaran; (c) media dan sistem penyampaian.

Pendekatan desain pembelajaran dan pengembangan berasumsi bahwa pengajaran harus bervariasi, disesuaikan kepada jenis tugas belajar tertentu. Keputusan tentang desain pengembangan penting lainnya, adalah pemilihan media dan sistem penyampaiannya, dituntun oleh prinsip-prinsip instruksional, yang memfasilitasi keterlibatan peserta didik dalam kegiatan "real-world".

\footnotetext{
15 Richey \& Klein. ibid. p. 4.
} 
3. Communication theory and message design research (Teori Komunikasi Dan Penelitian Desain Pesan)

Faktor yang ketiga ini berkaitan dengan media dan sistem penyajiannya.

4. Design \& development theory and research (Teori Desain, Pengembangan dan Penelitian). Faktor keempat ini melengkapi pemahaman yang sudah didapat dari ketiga basis sebelumnya, yakni desain dan pengembangan berbasis pengetahuan.

Keempat aspek tersebut divisualisasikan dalam gambar berikut ini:

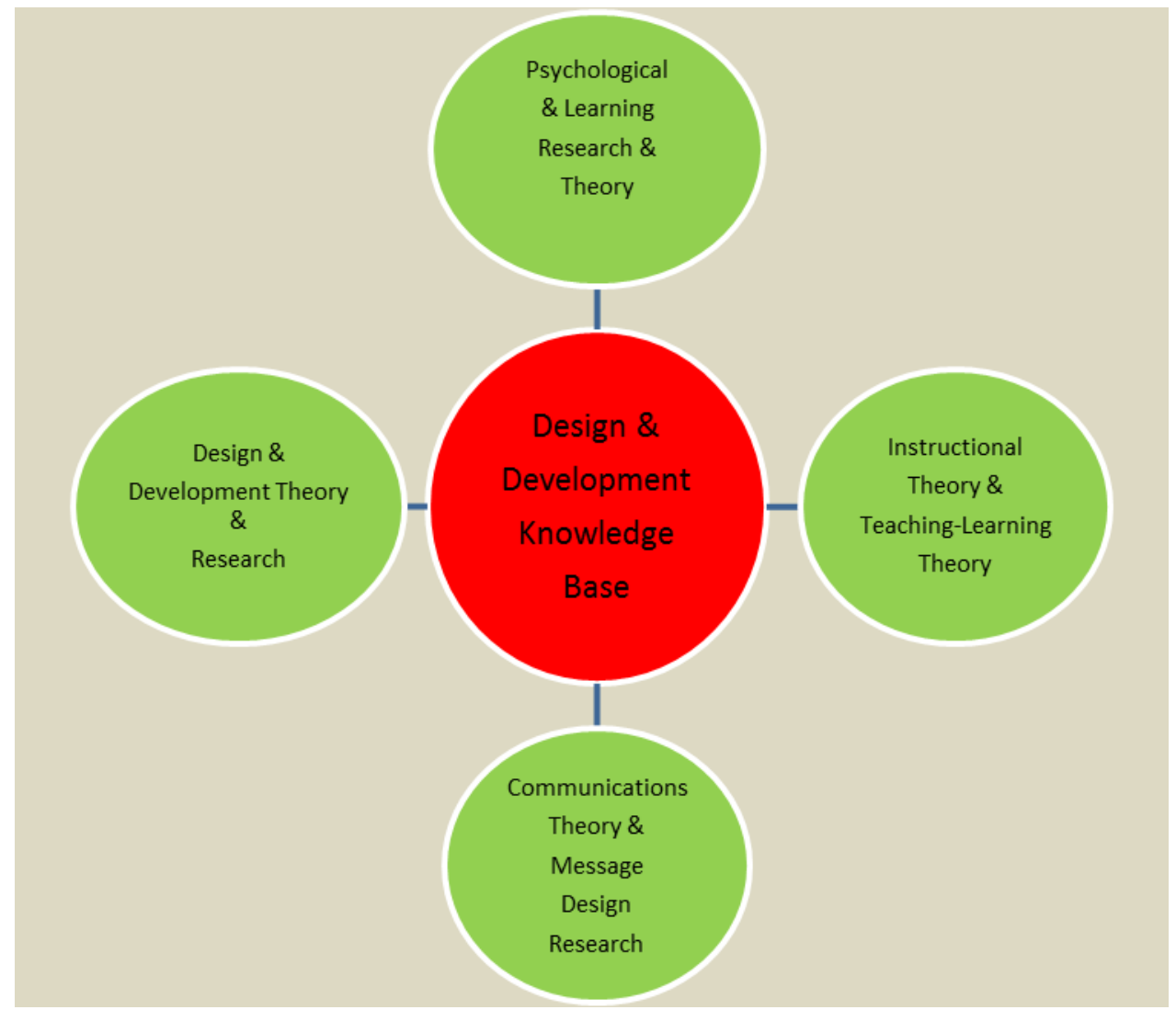

Gambar 2

Dasar-Dasar Teori Rancangan Penelitian dan Pengembangan Basis Pengetahuan menurut Richey \& Klein ${ }^{16}$

${ }^{16}$ Richey \& Klein,ibid., 2007:7 


\section{Karakteristik Metode Penelitian \& Pengembangan (R \& D)}

Metode R\&D atau yang disebut DDR oleh Richey \& Klein adalah rancangan penelitian dan pengembangan yang menggunakan sejumlah metode dan strategi yang luas baik kuantitatif maupun kualitatif. Metode mana yang dipilih dan bagaimana penerapannya bergantung pada sifat masalah penelitian dan rumusan pertanyaan-pertanyaan serta pada jenis penelitian yang dilakukan, apakah penelitian produk dan alat, ataukah penelitian model.

Berikut ini adalah metode-metode yang umum digunakan dalam penelitian dan pengembangan menurut Richey \& Klein:

\section{Tabel 1}

Metode-Metode yang Digunakan dalam Penelitian dan Pengembangan ${ }^{17}$

\begin{tabular}{|l|l|l|}
\hline Jenis Riset & Project emphasis & Research methods employed \\
\hline $\begin{array}{l}\text { Product \& tool } \\
\text { research }\end{array}$ & $\begin{array}{l}\text { Comprehensive design \& } \\
\text { development projects }\end{array}$ & $\begin{array}{l}\text { Case study, content analysis, evaluation, } \\
\text { field observation, in-depth interview }\end{array}$ \\
\hline $\begin{array}{l}\text { Product \& tool } \\
\text { research }\end{array}$ & $\begin{array}{l}\text { Phases of design \& } \\
\text { development }\end{array}$ & $\begin{array}{l}\text { Case study, content analysis, expert review, } \\
\text { field observation, in-depth interview, survey }\end{array}$ \\
\hline $\begin{array}{l}\text { Product \& tool } \\
\text { research }\end{array}$ & Tool development \& use & $\begin{array}{l}\text { Evaluation, expert review, in-depth } \\
\text { interview, survey }\end{array}$ \\
\hline Model research & Model development & $\begin{array}{l}\text { Case study, in-depth interview, } \\
\text { literature review, survey, think aloud } \\
\text { methods }\end{array}$ \\
\hline Model research & Model validation & $\begin{array}{l}\text { Experimental, expert review, in-depth } \\
\text { interview }\end{array}$ \\
\hline Model research & Model use & $\begin{array}{l}\text { Case study, content analysis, field } \\
\text { observation, in-depth interview, survey, } \\
\text { think-aloud methods }\end{array}$ \\
\hline
\end{tabular}

Tabel di atas menggambarkan bahwa penelitian desain dan pengembangan : lebih bergantung kepada teknik kualitatif daripada kuantitatif; bila melihat literatur penelitian rancangan dan pengembangan, menunjukkan

${ }^{17}$ Rita C. Richei and James D. Klein. Development Research Method: Creating Knowledge from Instructional Design and Development Practice. Journal of Computing in Higher Education, Spring 2005; Vol 16 (2)p.p. 23-38, tersedia pada http://apling.engl.iastate.edu/tsll/2008/DBRodriguezPardo.pdf 
bahwa studi-studi tersebut cenderung terkait proyek dalam kehidupan nyata daripada proyek simulasi; dan yang dan penelitian rancangan dan pengembangan, kebanyakan menggunakan berbagai metode penelitian atau metode penelitian campuran.

Produk yang dihasilkan dalam research and development bermacammacam. Sebagai contoh dalam bidang teknologi, orientasi produk teknologi yang dapat dimanfaatkan untuk pengajaran bahasa asing, misalnya program CALL (Computer Asssitant Language Learning).

\section{Langkah-langkah Penelitian dan Pengembangan.}

Semiawan mengemukakan bahwa siklus dasar $R \& D$ selalu mencakup siklus kajian - evaluasi - pengembangan. ${ }^{18}$ Sementara itu prosedur $R \&$ $D$ digambarkan oleh Sugiyono dalam langkah-langkah sebagai berikut:

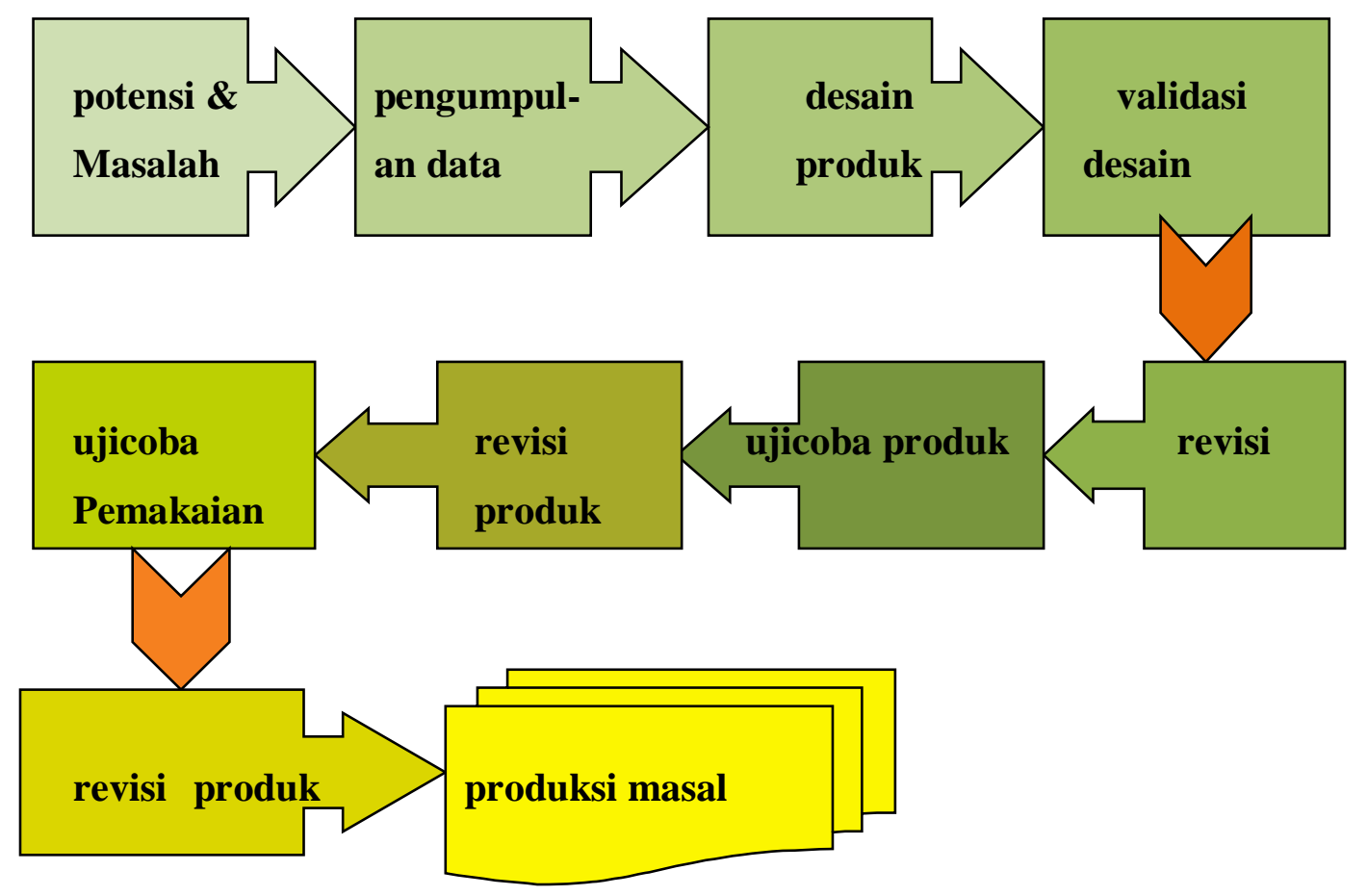

Gambar. 3

Langkah-langkah penggunaan metode Research \& Development ${ }^{19}$

${ }^{18}$ Semiawan, Conny R. Catatan kecil tentang penelitian dan pengembangan ilmu Pengetahuan. Jakarta: kencana. 2007: h. 184

19 Sugioyono. Metode Penelitiian dan R \& D, Alpabeta, Bandung. 2008: h. 298. 


\section{(1) Potensi dan masalah.}

Penelitian pengembangan Dilakukan karena adanya potensi atau masalah yang bila didayagunakan akan memiliki nilai tambah. Sebagai contoh, dalam bidang budaya. Budaya bangsa beraneka ragam, diantaranya termasuk keragaman bahasa. bahasa adalah identitas budaya dan alat berbudaya. Bahasa sebagai alat komunikasi dan alat untuk berbagi ide dan transfer budaya antar individu dan masyarakat. Oleh karenanya bahasa mengalami perubahan seiring perubahan waktu dan kemajuan budaya masyarakat. dengan demikian bahan ajar bahasa juga perlu diselaraskan sesuai kemajuan budaya, dan perubahan kebutuhan peserta didik.

Contoh lain dalam kehidupan sehari-hari salah satu kegiatan yang disenangi para siswa adalah menyanyi. Potensi menyanyi ini dapat dimanfaatkan dalam pembelajaran bahasa asing ntuk meningkatkan kosakata dan ketrampilan menyimak dalam suasana yang menyenangkan. Berdasarkan hal ini maka dapat dikembangkan model pembelajaran bahasa asing melalui lagu atau nyanyian. Hal ini dapat dijadikan potensi apabila kita dapat mendayagunakan lagu-lagu. Menyanyi dapat dijadikan potensi bila kita dapat menggunakannya dalam proses pembelajaran dengan menggunakan gerakan.

Masalah adalah merupakan penyimpangan antara yang diharapkan dengan kenyataan. Hal ini dapat diatasi melalui penelitian pengembangan dengan cara meneliti sehingga dapat ditemukan suatu model, pola atau sistem penanganan terpadu yang dapat digunakan secara efektif untuk mengatasi masalah tersebut. Sehubungan dengan contoh di atas, langkah yang digunakan tahap pertama adalah melakukan penelitian untuk menghasilkan informasi tentang kemampuan dan penguasaan kosakata dan ketrampilan menyimak bahasa dalam bahasa asing para siswa.

Metode penelitian yang dapat digunakan adalah metode kualitatif. Berdasarkan data yang diperoleh, selanjutnya dapat dirancang model penanganan masalah yang efektif. Untuk mengetahui efektifitas model tersebut, maka perlu diuji. Pengujian dapat menggunakan metode eksperimen. Setelah model teruji, maka dapat diaplikasikan untuk mengatasi masalah kosakata dan ketrampilan menyimak para siswa. 
Potensi dan masalah yang dikemukakan dalam penelitian harus ditunjukkan dengan data empirik. Misalnya, masalah yang disampaikan di atas tadi adalah masalah kosakata dan ketrampilan menyimak siswa yang rendah harus dapat dikemukakan lewat data, seperti hasil tes kemampuan menyimak dan metode mengajar ketrampilan menyimak yang digunakan.

Data tersebut selanjutnya dapat digunakan untuk merancang atau mendesain suatu model lainnya yang dapat membantu para siswa dalam meningkatkan kosakata dan ketrampilan menyimak mereka. Data tentang potensi dan masalah dapat ditemukan melalu hasil laporan penelitian orang lain, atau dokumentasi laporan kegiatan dari perorangan atau instansi tertentu yang masih up to date.

Mengidentifikasi masalah penelitian dan pertanyaan-pertanyaan yang berhubungan merupakan langkah pertama dalam merencanakan studi empiris. Masalah penelitian dalam desain dan pengembangan harus mengarah pada pertanyaan-pertanyaan penting yang dapat memberikan kontribusi kepada pengetahuan dan perbaikan praktek di lapangan.

Pedoman untuk memilih masalah penelitian. Patten dalam Richey \& Klein, menganjurkan para peneliti pemula dalam memilih masalah untuk memulai dengan mengidentifikasi beberapa bidang masalah yang luas yang diminati dan kemudian mengevaluasi setiap bidang dengan mengajukan pertanyaan: "is the problem area in the mainstream of the field?" "is there a substantial body of literature in the area?" "is the problem timely?"20

Gall, Gall \& Borg menyarankan agar masalah penelitian didasarkan pada faktor- faktor seperti (a) significance (kebermaknaan): “is it important?", (b) feasibility (kelayakan): "do you have the resources and expertise necessary to study it?" dan (c) benefit (manfaat): "is it directly related to your professional goals?".21

Nilai, keaslian, dan relevansi suatu penelitian desain dan pengembangan bergantung kepada masalah yang diteliti. Pencarian masalah penelitian

\footnotetext{
20 Patten dalam Richey \& Klein, op.cit. 2007:15

21 Borg, W.R, And Gall, M.D. Education Research an Inroduction. London: Longman, Inc. 2007:16
} 
merupakan bagian penting dari sebuah usaha penelitian. Pencarian diawali dengan merubah topik yang diminati ke dalam identifikasi masalah yang layak diteliti. Masalah yang baik bukan hanya diminati oleh peneliti, tetapi juga oleh para professional lainnya. Masalah yang baik bagi peneliti, jika masalah itu dapat menerapkan pengetahuan, ketrampilan dan pengalamannya. Masalah yang baik dapat dapat diatasi dalam waktu yang tersedia.

Menurut Richey, eksplorasi relevansi penelitian adalah eksaminasi khusus dari persepsi bersama, di mana relevansi, gagasan (notion) peneliti sesuai dengan persepsi dan kebutuhan praktisi.

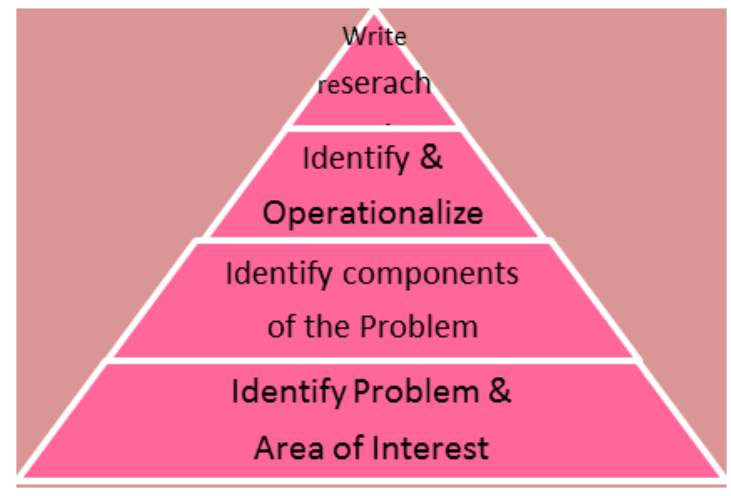

Gambar 4.

Narrowing the Research Topic

\section{(2 )Mengumpulkan informasi}

Setelah potensi dan masalah dapat ditunjukkan secara factual dan up to date, maka berbagai informasi dikumpulkan untuk perencanaan produk atau model tertentu yang diharapkan dapat mengatasi masalah tersebut. Oleh karena itu, diperlukan metode penelitian tersendiri yang sesuai permasalahan dan tujuan khusus yang hendak dicapai. Misalnya pendidik akan mengadakan penelitian untuk menghasilkan produk atau model tertentu yang dapat meningkatkan kosakata dan ketrampilan menyimak para siswa.

Dalam hal ini, pendidik perlu melakukan penelitian di kelas atau di sekolah tertentu. Bila hasil pengamatan menunjukkan bahwa yang menyebabkan rendahnya kosakata dan ketrampilan menyimak adalah model pembelajaran yang tidak kontekstual, maka peneliti perlu membuat model baru yang diharapkan dapat meningkatkan kosakata dan ketrampilan menyimak para siswa. 


\section{(3) Rancangan Desain Penelitian dan Pengembangan}

Suatu desain penelitian yang baik memberikan arah untuk menjawab petanyaan-pertanyaan yang diajukan dalam masalah penelitian atau untuk menguji hipotesis solusi penyelesaian masalah. Suatu desain yang baik juga dapat membimbing tentang bagaimana penemuan-penemuan dapat diaplikasikan dalam situasi lain. Mendesain penelitian merupakan suatu proses perencanaan. Desain penelitian biasanya disebut blueprints (cetak biru) yang menuntun para peneliti dalam penelitian. Suatu desain penelitian menetapkan kerangka umum studi dengan memberi arah setiap fase dari proses penelitian.

Para peneliti mendesain studi mereka lalu mengimplementasikannya secara fleksibel pada saat merespons situasi-situasi yang muncul selama penelitian berlangsung. Desain penelitian itu bervariasi, bergantung kepada tujuan studinya. Apakah berorientasi kuantitatif ataukah kualitatif ?. Namun, terdapat beberapa hal umum yang harus dipertimbangkan pada waktu mendesain suatu penelitian, yaitu:

- Menetapkan validasi kesimpulan akhir

- Menetapkan kondisi agar kesimpulan kausal dan pernyataan-pernyataan yang tegas dapat diterima.

- Memfasilitasi generalisasi dan interpretasi

- Mengantisipasi masalah yang dapat timbul dalam proses pelaksanaan penelitian.

\section{Komponen-komponen Desain Penelitian.}

Suatu desain penelitian yang komprehensif menjelaskan keputusankeputusan tentang:

- Jenis observasi yang digunakan untuk pengumpulan data yang akan diperlukan dalam menjawab pertanyaan-pertanyaan penelitian atau menguji hipotesis,

- Strategi-strategi yang digunakan atau metode penelitian yang akan diterapkan.

- Variabel-variabel yang berpusat pada studi dan variabel-variabel yang yang harus dikontrol

- Partisipan dalam proyek penelitian 
- Instrumen dan pengukuran variabel

- $\quad$ Analisis data

\section{(4) Validasi desain}

Validasi desain merupakan proses kegiatan untuk menilai apakah rancangan produk yang baru, sebagai salah satu contoh,"sistem kerja CALL (Computer Asssitant Language Learning) untuk meningkatkan kosakata dan ketrampilan menyimak, secara rasional lebih efektif dari yang lama. Dikatakan secara rasional, karena validasi pada tahap ini masih bersifat penilaian berdasarkan pemikiran rasional, belum fakta lapangan.

Kegiatan validasi produk dilakukan dengan menghadirkan pakar atau ahli untuk menilai produk baru yang didesain. Validasi desain produk bertujuan untuk mengetahui kelemahan maupun kekuatannya. Validasi desain dapat dilakukan di dalam suatu forum di mana peneliti mempresentasikan proses penelitian dan keunggulan desainnya.

Validasi Model Id (Instructional Design) dapat dipandang baik sebagai validasi internal dari komponen dan proses model, atau sebagai validasi eksternal dari dampak produk suatu penggunaan model. Focus validasi internal menilai beberapa masalah-masalah, seperti:

- apakah semua langkah di dalam model itu diperlukan?

- apakah langkah-langkah itu dapat diatur dalam urutan yang ditentukan?

- $\quad$ sejauh mana model ini mencakup semua faktor lingkungan yang relevan?

- dapatkah langkah-langkah dilaksanakan secara efisien dalam berbagai setting penelitian?

- $\quad$ apakah penggunaan model ini biaya terjangkau dan efektif ${ }^{22}$

Validasi eksternal menilai masalah-masalah seperti:

- sejauh mana hasil produk model pembelajaran itu memenuhi kebutuhan peserta didik, kebutuhan klien, dan persyaratan klien?

- $\quad$ sejauh mana instruksi itu menghasilkan pembelajaran yang efisien?

- $\quad$ sejauh mana perubahan perilaku yang dihasilkan berdampak terhadap kinerja organisasi/institusi?

\footnotetext{
${ }^{22}$ Richey, 2005 dalam richey \& klein, 2007:23)
} 


\section{( 5) Revisi desain}

Setelah produk desain divalidasi oleh para ahli maka dapat diketahui kelemahannya untuk diperbaiki oleh peneliti dan didesain ulang.

\section{(6) Uji coba produk}

Setelah desain produk divalidasi dan direvisi maka produk tersebut diuji cobakan dalam bentuk prototipe. Uji coba dilakukan pada kelompok terbatas untuk mendapatkan masukan apakah produk tersebut lebih efektif dan efisien dibandingkan dengan produk lama atau produk yang lainnya.

Pengujian dapat dilakukan dengan eksperimen, di mana efektiftas dan efisien produk lama dengan yang baru dibandingkan. Dalam uji coba ini dapat digunakan one-group pretest-posttest yang oleh Sugiyono disebut desain eksperimen before-after, ${ }^{23}$ atau digunakan desain eksperimen dengan dua kelompok yaitu kelompok eksperimen dan kelompok kontrol. Untuk menguji signifikansi perbedaan efektifitas dan efisiensi produk baru dibanding produk lama perlu diuji secara statistik dengan $t$-test.

\section{(7) Revisi produk}

Jika dalam uji coba ditemukan kekurangan dan kelemahan dari produk yang baru maka perlu diadakan lagi revisi untuk memperbaiki hal tersebut sebelum produk ini diterapkan dalam kondisi yang nyata untuk lingkup yang luas.

\section{(8) Uji coba pemakaian}

Setelah pengujian terhadap produk terhadap produk berhasil dilaksanakan, dan beberapa revisi selesai dilakukan, maka selanjutnya produk baru tersebut diterapkan dalam kondisi nyata untuk lingkup yang luas. Dalam penerapannya produk tersebut harus dinilai kekurangan atau hambatan yang muncul guna perbaikan lebih lanjut.

\footnotetext{
${ }^{23}$ sugiyono (2008:303)
} 


\section{(9) Revisi produk}

Langkah ini ditempuh hanya jika setelah uji coba yang terakhir masih ditemukan beberapa kekurangan dan kelemahan pada produk yang baru. Proses penyempurnaan ini sangat diperlukan agar tujuan akhir penelitian ini benar-benar dapat tercapai.

\section{(9) Pembuatan produk masal}

Pembuatan produk masal ini dilakukan apabila produk yang telah diujicoba dinyatakan efektif dan layak untuk diproduksi masal. Sebagai contoh pembuatan web site universitas sebagai mekanisme penerimaan mahasiswa baru; pengembangan materi ajar muatan lokal melalui cerita daerah; bahan ajar bahasa asing untuk pemandu wisata lokal; dan lain-lain.3.

\section{Memilih Seting Penelitian dalam Riset Pengembangan}

Untuk memilih setting peneliti perlu mengetahui tipe dan karakteristik setting yang dipilih. Dalam memilih setting atau lapangan penelitian ini, tentu disesuaikan dengan bidang keahlian peneliti.

Dalam memilih setting penelitian, tentu seorang peneliti akan menyesuaikannya dengan pertanyaan penelitian yang akan dijawab. Maka pemilihan setting penelitian ini juga bergantung pada fokus penelitian yang dipilih dan ditetapkan.

\section{Isu kritis dalam pemilihan setting penelitian}

Jika setting atau lapangan penelitian telah ditemukan secara sempurna dan benar sesuai dengan pertanyaan penelitian, maka ada beberapa isu penting yang perlu disepakati.

Pertama, feasibility (kelayakan) suatu setting atau lapangan dan partisipan penelitian untuk sebuah desain studi pengembangan. Kelayakan yang dimaksudkan adalah adanya kemungkinan penelitian itu dapat dilakukan dan berhasil mencapai tujuan. Misalnya ketersedian sumber data, dukungan dari pihak pimpinan atau yang terkait, dan sebagainya.

Kedua, isu yang berhubungan dengan akses yang disediakan oleh organisasi. Kekurangan akses terhadap partisipan dalam setting penelitian 
bisa menghambat pelaksanaan satu desain studi pengembangan. Misalnya saja tahun 2001 seorang peneliti telah menyusun suatu desain pengembangan model pembelajaran bahasa asing pada suatu lembaga pendidikan untuk menilai apakah desain pengembangan memiliki nilai inovatif untuk memperbaiki kualiatas pembelajaran, ternyata sejak 11 september di tahun itu akses terhadap personil sekolah setting penelelitian dibatasi, akhirnya rencana penelitian itu tidak pernah dilaksanakan.

Ketiga, adalah penting untuk mempertimbangkan apakah organisasi yang akan diteliti akan memberi akses kepada data dan memberi ijin menerbitkan hasil riset di luar internal perusahaan. ${ }^{24}$ Suatu hal yang luar biasa bagi seorang manajer senior yang mau menyetujui satu laporan penelitian apalagi mempublikasikannya.

\section{Instrumen pengumpulan data}

Peneliti yang mempelajari desain dan pengembangan cenderung untuk menggunakan berbagai macam instrumen pengumpulan data. Sebagai contoh, Mc Kenney (2002) menggunakan enam kategori perangkat (tools) pengumpulan data dalam pengembangan produk penelitiannya,

Display data merupakan acara penting peran kritis dimana instrumen pengumpulan data bermain dalam satu desain dan proyek penelitian pengembangan. Sementara itu kita tidak akan menghadapi prinsip dasar desain instrumen di sini, beberapa pengumpulan data yang dapat digunakan dalam $\mathrm{r} \& \mathrm{~d}$ diantaranya.

\section{1). Panduan wawancara}

Wawancara adalah bentuk perbincangan, seni bertanya dan mendengar.

Penggunaan wawancara dalam penelitian sosial dalam berbagai bidang dan bentuk, wawancara hendaknya dilakukan dengan penuh keterbukaan, keterlibatan emosional dan kepercayaan antara peneliti dan subjek penelitian. Tawaran ini ini berdasarkan etika feminism yang memiliki komitmen kesetaraan antara peneliti dan subjek peneliti.

24 Richey \& Klein. op.cit. 2007: 86) 
Etika feminis ini pula merubah teknik wawancara menjadi alat penting bagi pengembangan model-model penelitian. (saifuddin zuhri qudsy, 2009, h. 4970)

\section{2). Observasi}

Observasi juga merupakan metode pengumpulan data kualitatif yang paling banyak digunakan dalam penelitian kualitatif terutama dalam pengumpulaan data sosial, metode observasi alami merupakan langkah awal dalam observasi partisipan yang lebih luas.

Riset dan pengembangan sebagai salah satu bentuk penelitian kualitatif murni atau gabungan, tetap menggunakan observasi sebagai metode pengumpulan data. Kegiatan observasi dilakukan dalam riset pengembangan pada saat peneliti melakukan uji coba pengembangan produk atau uji coba strategi, metode, media atau bahan ajar misalnya di dalam dunia pendidikan. (saifuddin zuhri qudsy, 2009, h. 4970)

Penggunaan dua metode di atas dalam penlitian pengembangan sejak peneliti melakukan penelitian pendahuluan untuk menemukan masalah yang akan dipecahkan melalui riset pengembangan, saat peneliti ingin mengetahui kondisi atau kebutuhan yang perlu dipenuhi, bahkan juga pada tahap validasi desain pengembangan, uji coba produk pengembangan.

\section{3) visualisasi}

visualisasi juga tepat digunakan dalam mendukung data hasil observasi. Visualisasi biasanya dilakukan dengan membuat film, video, fotografi untuk mencatat dan mendokumentsikan kehidupan sosial,(saifuddin zuhri qudsy, 2009, h. 4970) termasuk dalam uji coba pengembangan model, strategi, metode dan bahan ajar atau bahkan uji coba kurikulum

4). Selain tiga metode di atas, tes juga dapat digunakan dalam penelitian pengembangan. Misalnya pada penelitian pengembangan strategi, metode mengajar, pada akhir uji coba produk pengembangan 
peneliti perlu mengatahui hasil belajar siswa dengan menggunakan metode atau strategi baru yang ditemukan dan telah diuji cobakan pada tahap pengembangan. Melalui tes ini dapat diketahui efektifitas, keunggulan suatu strategi atau metode yang dikembangkan.

\section{Kesimpulan}

Inovasi pembelajaran adalah suatu keniscayaan yang harus terjadi dan diupayakan agar mutu pendidikan meningkat. Inovasi pembelajaran itu diperlukan dalam berbagai aspek dan faktor pendidikan, baik sarana, kurikulum, proses pembelajaran, evaluasi pendidikan maupun peningkatan mutu guru dan peningkatan kesadaran dan partisipasi peserta didik. salah satu kegiatan inovasi pendidikan adalah pengembangan bahan ajar. Bahan ajar harus selalu di perbaharui dan disesuaikan dengan kebutuhan peserta didik. Cara efektif bagi pengembangan bahan ajar adalah dilakukan melalui penelitian pengembangan. 


\section{DAFTAR PUSTAKA}

Borg, W.R, And Gall, M.D. Education Research an Inroduction. London:

Longman, Inc. 2007:16

Rogers, Everett M, Diffusion of Inovations. USA, 1995:

Richey dan Klein, Design and development research-methods, strategies and issues. London: Lawrence Erlbaum Associates, Inc., Publishers, 2007

Rita C. Richei and James D. Klein. Development Research Method: Creating Knowledge from Instructional Design and Development Practice. Journal of Computing in Higher Education, Spring 2005; Vol 16 ( tersedia pada http://apling.engl.iastate.edu/tsll/2008/DBRodriguezPardo.pdf

Semiawan, Conny R. Catatan kecil tentang penelitian dan pengembangan ilmu Pengetahuan. Jakarta: kencana. 2007.

Sugioyono. Metode Penelitiian dan R \& D, Alpabeta, Bandung. 2008: h. 298.

Udin Saefudin Sa'ud, Inovasi Pendidikan, Bandung, Alfabeta, 2008: h. 8

www.jst.go.jp/crds/pdf/methodology/CRDS-FY2010-XR-25E.pdf

myweb.fsu.edu/jklein/articles/Richey_Klein_2005.pdf

apples.jyu.fi/ArticleFile/download/262

www.professorjackrichards.com/wp-content/uploads/materials-development-

making-connection.pdf

www.tojet.net/articles/v11i2/11211.pdfS

research-publishing.net/publication/978-1-908416-00-1.pdf

downloads.slo.nl/Documenten/educational-design-research-part-a.pdf

dspace.ou.nl/bitstream/1820/4992/1/Reeves\%26McKenneyTypeset.

ies.ed.gov/pdf/CommonGuidelines.p

http://apling.engl.iastate.edu/tsll/2008/DBR Rodriguez Pardo.pdf

www.arbor.edu/wp-content/uploads/2012/12/ESL326.pdf

web.stanford.edu/ hakuta/Courses/Ed205X\%20Website/Resources/Ellis\%20Instr ucted-second-language $\% 20(2)$.pdf 